\title{
POTENSI BAKTERI Lactobacillus acidophilus SEBAGAI ANTIDIARE DAN IMUNOMODULATOR
}

\section{POTENTIAL OF Lactobacillus acidophilus BACTERIA AS ANTIDIARE AND IMMUNOMODULATOR}

\author{
Rusli $^{1}, \quad$ Fitri Amalia ${ }^{1}$, Zaraswati Dwyana $^{2}$ \\ ${ }^{1}$ Fakultas Farmasi Universitas Muslim Indonesia, Makassar \\ ${ }^{2}$ Departemen .Biologi, FMIPA Universitas Hasanuddin, Makassar \\ zaraswatidwyana@gmail.com
}

\begin{abstract}
Abstrak
Probiotik adalah kelompok mikroorganisme yang sangat menguntungkan bagi kesehatan tubuh manusia. Kelompok bakteri yang tergolong probiotik adalah kelompok bakteri asam laktat yang merupakan mikroflora alami pada saluran pencernaan manusia dan dapat memproduksi bakteriosin yang dapat merangsang pembentukkan antibodi tubuh dan dapat dimanfaatkan sebagai imunomodulator dan antidiare. Probiotik yang digunakan adalah Lactobacillus acidophilus dan dilakukan pengujian potensi antidiare dengan mengunakan metode difusi agar serta pengujian potensi imunomodulator dilakukan secara in vivo dengan hewan uji mencit. Hasil penelitian kemampuan antibakteri terhadap penyebab diare E.coli diketahui L.acidophilus dapat menghambat pertumbuhan E.coli pada semua konsentrasi dan terjadinya peningkatan aktivitas imunoglobulin setelah pemberian isolat bakteriLactobacillus acidophilus FNCC 005 pada hewan uji.
\end{abstract}

Kata kunci : L.acidophilus, antidiare, imunomodulator

\begin{abstract}
Probiotics are a group of microorganisms that are very beneficial for the health of the human body. The group of bacteria classified as probiotics is a group of lactic acid bacteria which is a natural microflora in the human digestive tract and can produce bacteriocins which can stimulate the formation of body antibodies and can be used as immunomodulators and antidiarrhea. The probiotic used was Lactobacillus acidophilus and antidiare potential testing was carried out using agar diffusion method and testing the potential of immunomodulators carried out in vivo with mice test animals. The results of the study of antibacterial ability against the causes of E. coli diarrhea are known to L.acidophilus can inhibit E.coli growth at all concentrations and the increase in immunoglobulin activity after administration of Lactobacillus acidophilus FNCC 005 bacterial isolates in test animals.
\end{abstract}

Keywords: L.acidophilus, antidiare, immunomodulators 


\section{Pendahuluan}

Lactobacillus telah lama dikenal sebagai flora normal yang berfungsi sebagai agen probiotik yang dapat menghambat pertumbuhan bakteri penyebab infeksi seperti diare...Lactobacillus dapat berfungsi untuk kekebalan tubuh karena bakteri ini mampu merangsang pembentukan antibodi yang mencegah kelebihan pertumbuhan bakteri berbahaya, mencegah timbulnya infeksi saluran kemih, meningkatkan perlindungan terhadap patogen, virus dan bakteri jahat, memulihkan keseimbangan usus setelah pemberian antibiotik, kemoterapi, mencegah pembentukan gas akibat pembusukan . Peningkatan daya tahan tubuh oleh Lactobacillus berhubungan dengan tingkat IgA. .Bakteri probiotik juga menstimulasi produksi sitokin dalam darah dan meningkatkan aktivitas makrofag.

\section{Metodologi Penelitian}

\section{Pengujian aktivitas antidiare}

Kultur bakteri probiotik Lactobacillus acidophilus dibuat suspensi dengan variasi konsentrasi $25 \%, 75 \%$ dan $100 \%$. Cawan petri yang telah berisi medium Nutrien Agar dan Escherichia coli dan dibiarkan memadat. Kultur bakteri Lactobacillus acidophilus FNCC 005 disuspensikan dengan aquadest steril. Setelah itu rendam kertas cakram dan diletakkan diatas permukaan medium Nutrient Agar lalu diinkubasi selama 1 x 24 jam.

\section{Pengujian aktivitas imunoglobulin pada hewan uji.}

\section{a. Pembuatan Suspensi Sel Darah Merah Domba (SDMD) 2\%}

Sebanyak $3 \mathrm{ml}$ darah domba ditampung dalam tabung yang bersih dan telah dikeringkan yang berisi dengan $1 \mathrm{mg} / 10 \mu \mathrm{L}$ EDTA yang berfungsi sebagai anti-koagulan. Kemudian disentrifugasi dengan kecepatan 1500 rpm untuk memisahkan sel darah merah domba (SDMD) dari plasmanya.Sel darah merah domba yang didapatkan dicuci dengan penambahan sejumlah besar Phosphat Buffered Saline (PBS) dalam tabung, lalu tabung tersebut dibolak-balik beberapa kali, setelah itu disentrifugasi kembali.Pencucian dilakukan paling sedikit 3 kali. Setelah disentrifugasi, PBS dikeluarkan sehingga yang tertinggal adalah SDMD 100\%, lalu ditambahkan lagi PBS dengan jumlah yang sama hingga diperoleh suspensi SDMD 50\%. Sebanyak 0,4 mL SDMD 50\% diencerkan dengan 9,6 ml PBS hingga diperoleh suspensi antigen (SDMD $2 \% \mathrm{v} / \mathrm{v}$ ).

\section{b. Pemilihan dan penyiapan hewan uji}

Hewan uji yang digunakan adalah mencit (Mus musculus) jantan yang sehat dengan bobot badan 20-30 gram, sebanyak 9 ekor mencit yang dibagi berdasarkan perlakuan dan dinyatakan telah teracak dengan baik jika bobot badan tiap mencit tidak berbeda nyata.

\section{c. Pengujian in vivo}

Kultur BAL probiotik Lactobacillus acidophilus 24 jam diencerkan pada aquadest steril dengan populasi $10^{8} \mathrm{CFU} / \mathrm{mL}$. Suspensi kultur E.coliyang diberikan adalah $10^{6} \mathrm{CFU} / \mathrm{mL}$.Pada mencit kontrol negatif dilakukan pemberian aquadest selama 6 hari dengan cara dicekoki untuk menyamakan tingkat stres yang dialami oleh mencit .

i. Perlakuan I (Kontrol negatif)

Mencit (Mus musculus) diberikan aquadest $1 \mathrm{~mL} / 30 \mathrm{~g}$ BB mencit secara oral selama 6 hari .Sampel darah diambil pada hari ke-2, 4dan 6.

ii. Perlakuan II (Pemberian Kultur L.acidophilus dan bakteri E.coli)

Mencit(Mus musculus) diberikan kultur bakteri Lactobacillus acidophilus sebanyak 1 $\mathrm{mL} / 30 \mathrm{~g}$ BB ekor mencit per hari secara oral menggunakan sonde (dicekok) selama 6 hari 
(hari ke-0 sampai ke-6). Suspensi bakteri E.colisebanyak $1 \mathrm{~mL} / 30 \mathrm{~g}$ BB ekor mencit per hari,selama dua hari (hari ke-3 sampai ke-4). Sampel darah diambil pada hari ke-2, 4 dan 6. iii. Perlakuan III (Kontrol Positif)

Suspensi E.coli yang diberikan adalah $10^{6} \mathrm{CFU} / \mathrm{mL}$ sebanyak $1 \mathrm{~mL} / 30 \mathrm{~g}$ BB ekor mencit per hari selama 6 hari (hari ke-0 sampai ke-6).Sampel darah diambil pada hari ke-2, 4 dan 6.

\section{d. Pengambilan sampel darah hewan uji}

Sampel darah hewan uji diambil secara vena lateralis pada hari ke-2, 4 dan 6 setelah imunisasi dan diletakkan pada suhu kamar selama 1-2 jam, lalu diambil supernatan dengan cara disentrifus selama 10 menit dengan kecepatan 3000 rpm.

\section{e. Uji hemaglutinasi}

Serum yang diperoleh lalu diencerkan secara "double dilution" dengan phosphat Bufferred Saline (PBS) dengan perbandingan 1/4, 1/8, 1/16, 1/32, 1/64, 1/128, 1/256, dan 1/ 512. Dari masing-masing perbandingan ini di pipet sebanyak $50 \mu \mathrm{L}$ dan diletakkan pada 8 sumur piring mikrotiter (well plate 96) isolat bakteri Lactobacillus acidophilus dan kontrol. Setelah itu, masing-masing ditambahkan 50 uL suspensi sel darah merah domba $2 \%$ pada setiap sumur dan digoyang-goyang selama 5 menit agar homogen. Selanjutnya di inkubasi pada suhu $37^{\circ} \mathrm{C}$ selama 60 menit dan didiamkan pada suhu kamar. Setelah itu dilakukan pengamatan pengenceran tertinggi dari setiap serum darah mencit jantan yang masih dapat mengaglutinasi sel darah merah domba.Dalam pembacaan titer hemaglutinin, hemaglutinasi dianggap positif jika seluruh atau sebagian besar permukaan yang cekung dasar lempeng tetes ditutupi oleh lapisan SDMD secara merata. Titer hemaglutinin dinyatakan sebagai kebalikan pengenceran serum yang masih menunjukkan hemaglutinasi.

\section{Hasil Dan Pembahasan}

\section{Hasil Pengujian aktivitas antidiare}

Aktivitas bakteri Lactobacillus acidophilus dilakukan uji pendahuluan dengan mengamati zona hambat yang dihasilkan terhadap pertumbuhan bakteri Escherichia coli. Hasil dari pengamatan zona hambat bakteri Lactobacillus acidophilus FNCC 005 dengan konsentrasi 25\%, 75\% dan 100\% terhadap pertumbuhan bakteri Escherichia coli (Gambar 1)

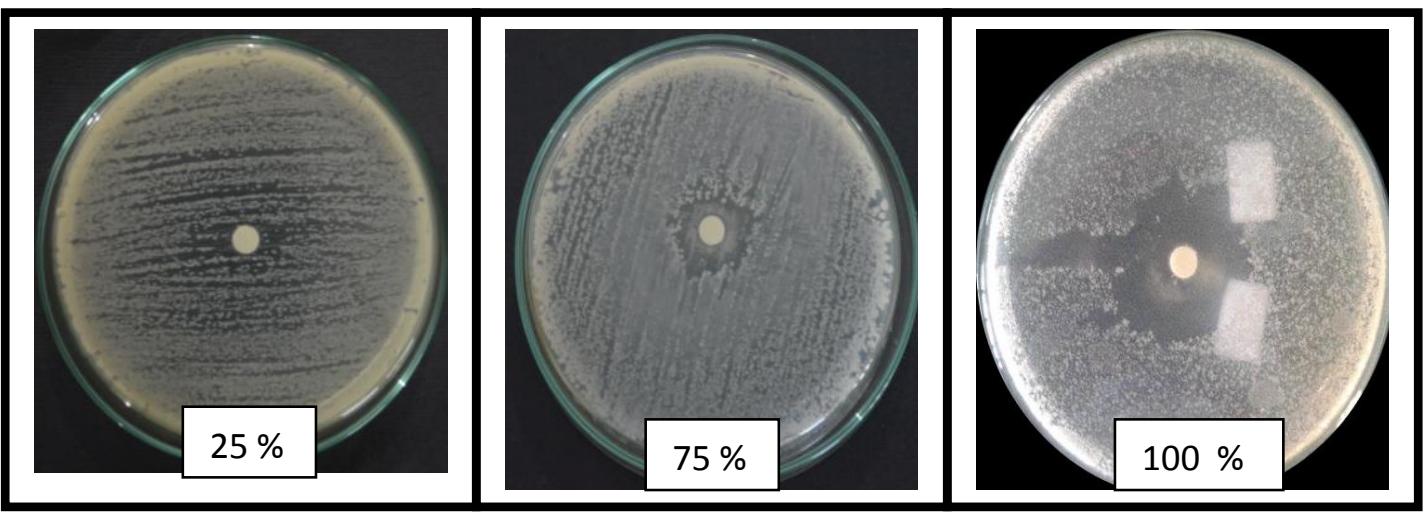

Gambar 1. Zona hambat bakteri Lactobacillus acidophilus FNCC 005 dengan variasi konsentrasi terhadap bakteri Escherichia coli 
Pemberian bakteri Lactobacillus acidophilus 25\%, $75 \%$ dan $100 \%$ menunjukkan diameter zona hambatan sebesar $12 \mathrm{~mm}, 23 \mathrm{~mm}$ dan $33 \mathrm{~mm}$. Semakin besar konsentrasi bakteri Lactobacillus acidophilus FNCC 005, maka semakin besar daya hambat yang dihasilkan terhadap pertumbuhan bakteri Escherichia coli.

\section{Hasil pengujian aktivitas imunoglobulin pada hewan uji}

Secara in vivo pemberian Lactobacillus acidophilus dan untuk mengetahui pengaruhnya sebagai penghasil imunomodulator dan antidiare pada mencit (Mus musculus)jantan pasca infeksi bakteri Escherichia coli. Darah mencit diambil secara vena lateralis pada ekor mencit untuk mengamati aktivitas imunoglobulin. Pengambilan darah untuk pengukuran imunoglobulin harus dilakukan sesuai dengan hari yang ditentukan, yaitu pada hari ke- 2, 4 dan 6setelah pemberian antigen. Selama kurun waktu tersebut, diharapkan telah terjadi sensitasi sel B yang akan berproliferasi, berdiferensiasi dan berkembang menjadi sel plasma yang memproduksi antibodi yaitu imunoglobulin.

Gejala infeksi E.coli dimulai pada hari ke-4 setelah pencekokan EPEC memperlihatkan secara umum feses pada grup mencit kontrol positif lembek danberlendir sebagai tanda telah terjadi infeksi pada saluran pencernaan mencit,sedangkan feses pada grup mencit yang lain tidak berlendir. Selain itu, dilihat dengan terjadinya penurunan bobot badan yang sangat nyata pada grup mencit kontrol positif pada hari ke-5, namuntidak ditemukan gejala tersebut pada grup mencitL.acidophilus+ E.coli dan grup kontrol negatif .

Tabel 1. Hasil Data Titer Imunoglobulin sesuai bentuk sumur mikrotiter (wellplate) terhadap mencit (Mus musculus) jantan selama 6 hari

\begin{tabular}{|c|c|c|c|c|c|c|c|c|c|c|c|c|}
\hline \multirow{3}{*}{$\begin{array}{l}\text { Pengenceran } \\
\text { Pada Sumur } \\
\text { Mikrotiter } \\
\text { (Well Plate) }\end{array}$} & \multicolumn{12}{|c|}{ JENIS PERLAKUAN } \\
\hline & \multicolumn{4}{|c|}{$\begin{array}{l}\text { Kontrol negatif } \\
\text { (Aquadest) }\end{array}$} & \multicolumn{4}{|c|}{$\begin{array}{c}\text { Isolat bakteri } \\
\text { L. acidophilusFNCC005 }\end{array}$} & \multicolumn{4}{|c|}{$\begin{array}{l}\text { Kontrol Positif } \\
(E . \text { colı) }\end{array}$} \\
\hline & $\begin{array}{l}\text { Hari } \\
\text { ke-0 }\end{array}$ & $\begin{array}{l}\text { Hari } \\
\text { ke-2 }\end{array}$ & $\begin{array}{l}\text { Hari } \\
\text { ke-4 }\end{array}$ & $\begin{array}{l}\text { Hari } \\
\text { ke-6 }\end{array}$ & $\begin{array}{l}\text { Hari } \\
\text { ke-0 }\end{array}$ & $\begin{array}{l}\text { Hari } \\
\text { ke-2 }\end{array}$ & $\begin{array}{l}\text { Hari } \\
\text { ke-4 }\end{array}$ & $\begin{array}{l}\text { Hari } \\
\text { ke-6 }\end{array}$ & $\begin{array}{l}\text { Hari } \\
\text { ke-0 }\end{array}$ & $\begin{array}{l}\text { Hari } \\
\text { ke-2 }\end{array}$ & $\begin{array}{l}\text { Hari } \\
\text { ke-4 }\end{array}$ & $\begin{array}{l}\text { Hari } \\
\text { ke-6 }\end{array}$ \\
\hline $1 / 4$ & + & + & + & + & + & + & + & + & + & + & + & + \\
\hline $1 / 8$ & - & + & + & + & + & + & + & + & - & + & + & + \\
\hline $1 / 16$ & - & + & + & + & + & + & + & + & - & + & + & + \\
\hline $1 / 32$ & - & + & + & + & - & + & + & + & - & + & + & + \\
\hline $1 / 64$ & - & + & + & + & - & + & + & + & - & + & + & + \\
\hline $1 / 128$ & - & - & + & + & - & + & + & + & - & + & + & + \\
\hline $1 / 256$ & - & - & + & + & - & + & + & + & - & - & + & - \\
\hline $1 / 512$ & - & - & - & + & - & + & + & + & - & - & + & - \\
\hline
\end{tabular}

Keterangan

(+) menunjukkan pengenceran tertinggi yang masih dapatmengaglutinasikan antigen

$(-)$ menunjukkan pengenceran tertinggi yang tidak dapat mengaglutinasikan antigen

(terdapatendapan)

Penggunaan sel darah merah domba (SDMD) 2\% yang merupakan imunogen. Sel darah merah domba (SDMD) merupakan antigen polivalen yang merupakan protein dengan determinan potensial yang lebih besar dibandingkan dengan antigen monovalen. Semakin asing antigen yang digunakan, semakin efektif menimbulkan respon imun.

Pengujian hemaglutinasi terhadap serum darah mencit dilakukan dengan menambahkan antigen yaitu sel darah merah domba. Pada umumnya antibodi memiliki lebih dari satu reseptor pengikat antigen sehingga antibodi bereaksi dengan molekul antigen lain yang mungkin sudah berikatan dengan salah satu molekul antibodi dan terbentuklah gumpalan. Gumpalan yang 
terbentuk antara antigen dan anti serum spesifik akan bersatu dan akhirnya mengendap sebagai gumpalan-gumpalan besar.Reaksi aglutinasi baru dapat terjadi bila rasio antara antigen dan antibodi seimbang, sehingga terbentuk zona ekuivalen Kresno (2004), dibantu oleh suhu yang tinggi $\left(37-56^{\circ} \mathrm{C}\right)$ dan oleh gerakan yang menambah kontak antigen dan antibodi (misalnya mengocok, mengaduk dan memutar) serta berkumpulnya gumpalan memerlukan garam-garam yang berasal dari PBS yang digunakan.

Pengamatan aktivitas imunoglobulin dilakukan dengan melihat titer antibodi yaitu pengenceran tertinggi dari larutan yang masih menunjukkan reaksi aglutinasi. Dari hasil perhitungan dengan mengonversi nilai titer antibodi dengan rumus [2 log (titer)] + 1, maka hasilnya dapat dilihat pada Gambar 2 yang menunjukkan terjadinya peningkatan aktivitas imunoglobulin setelah pemberian isolat bakteriLactobacillus acidophilus dengan perbandingan kontrol negatif dan kontrol positif.

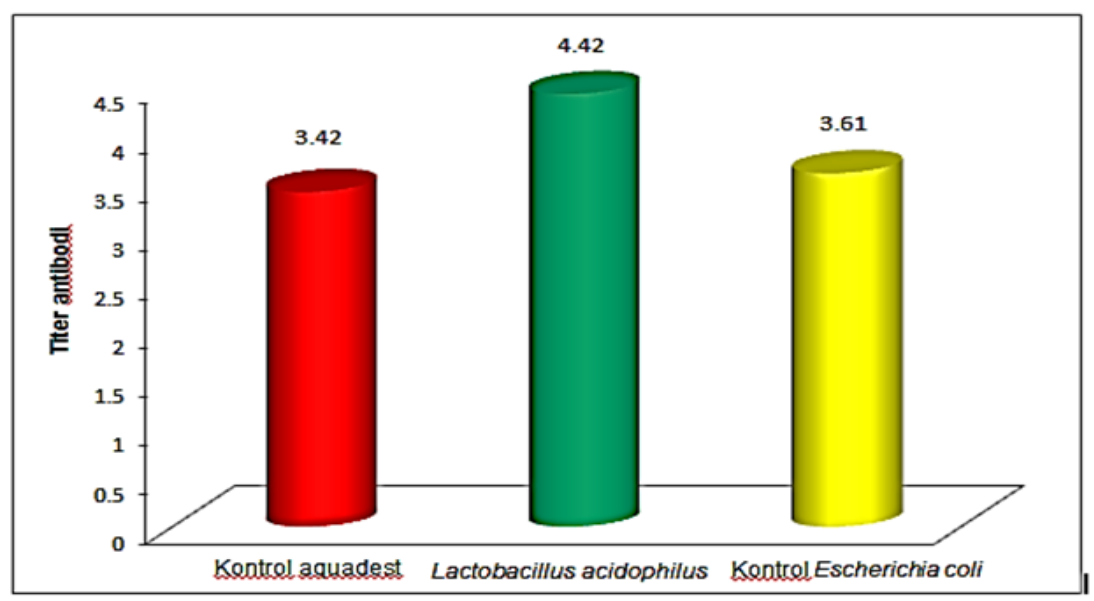

Gambar 2. Aktivitas Imunoglobulin.

Peningkatan jumlah imunoglobulin lebih tinggi pada kelompok perlakuan yang diberikan isolat bakteri Lactobacillus acidophilusjika dibandingkan dengan kontrol negatif yang hanya diberikan aquadest dan kontrol positif yang diberikan bakteri Escherichia coli, sehinggadiperoleh hasil bahwa peningkatan imunoglobulin lebih tinggi pada isolat bakteri Lactobacillus acidophilus FNCC 005 (gambar 2). Hal ini sesuai dengan penelitian yang telah dilakukan oleh Bintoro (2002) yang menyatakan bahwa bakteri asam laktat dapat hidup dan tumbuh di dalam saluran pencernaan. Bakteri asam laktat menghasilkan asam organik, senyawa antibiotika, enzim dan bakteriosin yang mampu menghambat pertumbuhan mikroorganisme patogen di dalam usus.Aktivitas dan produk metabolit yang dihasilkan bakteri asam laktat selama hidup di dalam saluan pencernaan dapat merangsang aktivitas sistem kekebalan tubuh.Pemberian Lactobacillus acidophilus FNCC 005 mampu meningkatkan aktivitas sistem kekebalan tubuh, ditandai dengan meningkatnya jumlah leukosit, limfosit, neutrofil, indek fagositik dan nilai titer antibodi.

Jepi (2011) menyatakan bahwa bakteri probiotik dapat memperkuat sistem imun karena adanya bantuan mukus. Melekatnya probiotik pada mukus ini ternyata diakibatkan oleh suatu zat protein yang dimiliki oleh probiotik tersebut. Zat tersebut dinamakan "mucus-binding protein" (protein pengikat mukus), yang ternyata dijumpai dalam jumlah yang lebih banyak pada bakteri penghasil asam laktat, dengan adanya protein ini maka bakteri probiotik dapat menempel pada mukus saluran cerna dan melakukan interaksi dengan host.. "Mucus-binding protein" mengenal protein imunoglobulin manusia yang merupakan bagian dari sistem imundan beberapa jenis 
bakteri asam laktat, seperti Lactobacillus casei, dapat meningkatkan respon imun sistemik yang mampu bertindak sebagai immunomodulators (Perdigon et.al., 1991).

Usus merupakan organ dengan sistem imun terluas di tubuh, sel-sel yang menyusun usus dilindungi oleh lapisan pelindung mukus yang secara terus-menerus mengalami proses regenerasi. Selain melindungi, ternyata mukus ini juga memberikan keuntungan bagi bakteri probiotik yaitu menjadi media melekatnya probiotik di dinding usus.Melekatnya probiotik pada mukus ini ternyata diakibatkan oleh suatu zat proteinyang dimiliki oleh probiotik tersebut, dari hasil penelitian diselidiki lebih jauh pada probiotik Lactobacillus reuteri.Zat tersebut dinamakan mucus-binding protein (protein pengikat mukus), yang ternyata dijumpai dalam jumlah yang lebih banyakpada bakteri penghasil asam laktat, dengan adanya protein ini maka bakteriprobiotik dapat menempel pada mukus saluran cerna dan melakukan interaksi dengan host. Mucus-binding protein ini juga mengenal protein imunoglobulin yang merupakan bagian dari sistem imun, oleh karena itu peranan mucus binding protein ini tampaknya akan lebih luas lagi selain sebagai media perlekatan probiotik pada dinding saluran cerna.

Pemberian Lactobacillus acidophilus FNCC 005 pada mencit yang diberi EPEC mempengaruhi sifat imunomodulator, yaitu meningkatkan jumlah immunoglobulin. Bakteri Asam Laktat (BAL) Lactobacillus acidophilus FNCC 005 memiliki potensi sebagai antidiare dan meningkatkan sistem imun (imunomodulator).

\section{Kesimpulan}

Bakteri Asam Laktat (BAL) Lactobacillusacidophilus FNCC 005 memiliki potensi sebagai antidiare dan meningkatkan sistem imun .

\section{Daftar Pustaka}

Astawan M. 2011. Potensi Bakteri Asam Laktat Probiotik Indigenus Sebagai Antidiare Dan Imunomodulator.J. Teknol.dan Industri Pangan, XXII (1)

Gusti, I P. 2011.Populasi Lactobacillus rhamnosus SKG34 Dalam Saluran Pencernaan Dan Pengaruhnya Terhadap Kadar Kolesterol Tikus Putih (Rattus norvegicus).Skripsi.Bali :Fakultas Bioteknologi.

Jepi, 2011.Uji Efek Isolat Bakteri Probiotik dari Susu Kerbau Terhadap Aktivitas Imunoglobulin G (IgG) Mencit (Mus musculus) Jantan.Skripsi.Makassar :Fakultas Matematika Dan IImu Pengetahuan Alam Universitas Hasanuddin.

Kusmardi. 2007. Efek Imunomodulator Ekstrak Daun Ketepeng Cina (Cassia Alata L.) Terhadap Aktivitas dan Kapasitas Fagositosis Makrofag.Jurnal.Makara Kesehatan, 11(2) : 50-53.

Kresno,S,B.2010.Imunologi : Diagnosis Dan Prosedur Laboratorium Edisi Kelima. Skripsi.Jakarta :Badan Penerbit Fakultas Kedokteran Universitas Indonesia.

Perdigon, G., M. Eugenia, S. Petrino and M. Valverde, 1991. Effect of oral administration of Lactobacillus casei on various biological functions of the host. Food and Agricultural Immunology, 3(2): 93.

Sri,G. 2010. Uji Efek Kultur Lactobacillus Casei Kering Terhadap Aktivitas Imunoglobulin M (lgm) Kelinci Oryctolagus Cuniculus Jantan.Skripsi.Makassar :Fakultas Matematika Dan Ilmu Pengetahuan Alam Universitas Hasanuddin. 